\title{
Analisis Kualitas Informasi Akuntansi Sebelum dan Sesudah Penerapan International Financial Reporting Standards (IFRS) Pada Perusahaan Manufaktur Yang Terdaftar Di B`EI
}

\author{
Iswanti Ninda Yacub ${ }^{1}$, Rindu Rika Gamayuni ${ }^{2}$ \\ Universitas Lampung
}

\begin{abstract}
ABSTRAK
Penelitian ini menguji pengaruh International Financial Reporting Standards (IFRS) Terhadap Kualitas Informasi Akuntansi dan Kualitas Laba yang diukur dengan relevansi informasi. Sampel dalam penelitian ini adalah perusahaan manufaktur yang terdaftar di BEI dengan tahun pengamatan selama delapan tahun yaitu empat tahun sebelum (20082011) dan empat tahun sesudah (2013-2014) dan diperoleh sampel sebanyak 31 sampel perusahaan. Hasil penelitian menunjukan bahwa penerapan IFRS mampu meningkatkan kualitas laba yang diukur dengan relevansi informasi akuntansi. Hasil ini juga menunjukkan bahwa terjadi peningkatkan relevansi nilai Book Value. Pada dimensi laba bersih perlembar saham (EPS), meskipun nilai coefficient EPS mengalami penurunan setelah penerapan IFRS, tetapi nilai EPS masih tetap memiliki arah yang positif terhadap harga saham. Dengan demikian, nilai relevansi BV lebih tinggi dibandingkan nilai relevansi EPS setelah penerapan IFRS.
\end{abstract}

Kata Kunci : IFRS, Relevansi Informasi Akuntansi, Informasi Akuntansi

\begin{abstract}
ABTRACK
This study examines the effect of International Financial Reporting Standards (IFRS) on the Quality of Accounting Information and Profit Quality as measured by the relevance of information. The sample in this study was a manufacturing company registered on the Stock Exchange with eight years of observation, namely four years before (2008-2011) and four years after (2013-2014) and a sample of 31 companies was obtained. The results of the study show that the application of IFRS is able to improve earnings quality as measured by the relevance of accounting information. This result also shows that there is an increase in the value relevance of Book Value. In the dimensions of net income per share (EPS), although the EPS coefficient value has decreased after the application of IFRS, but the value of EPS still has a positive direction on stock prices. Thus, the relevance value of $B V$ is higher than the value of relevance of EPS after the application of IFRS.
\end{abstract}

Keywords: IFRS, Relevance of Accounting Information, Accounting Information

\section{Pendahuluan}

Standar akuntansi yang berbasis Internasional mutlak diperlukan seiring dengan munculnya perkembangan bisnis pada perusahaan multinasional diberbagai negara, dalam perkembangan bisnis yang telah memasuki era globalisasi diperlukan adanya tuntutan satu standar akuntansi yang seragam digunakan oleh pasar modal atau perusahaan. Di Indonesia, sejak 1 Januari 2012 terjadi perubahan standard akuntansi keuangan, yaitu penerapan penuh standard akuntansi keuangan yang telah di-konvergensi dengan IFRS. 
Harmonisasi standar akuntansi dan pelaporan keuangan telah dianggap sebagai suatu hal yang mendesak dilakukan setiap negara termasuk Indonesia sebagai salah satu negara berkembang. Ikatan Akuntan Indonesia (IAI) sebagai pemegang kekuasaan tertinggi telah menetapkan untuk melakukan adopsi penuh atas IFRS. Penerapan IFRS diklaim akan memberi manfaat bagi peningkatan kualitas laporan keuangan.Keberhasilan implementasi IFRS, memiliki manfaat yang melebihi biaya, mempengaruhi tidak hanya perusahaan dalam Uni Eropa, tetapi juga perusahaan-perusahaan di seluruh dunia. Membuat IFRS semakin menjadi standar pelaporan global (Capkun et al., 2008). Namun, dalam proses adopsi penuh IFRS akan sulit dilakukan karena masih banyak regulasi yang tidak mendukung, entitas-entitas bisnis yang masih belum memiliki kesiapan, selain itu, perhatian dan komitmen yang kuat dari para pelaku bisnis, pemerintah Indonesia, dan otoritas pasar modal masih sangat minim (Hariyani dan Martini, 2015).

Penelitian mengenai dampak pengadopsian IFRS terhadap kualitas informasi akuntansi dan Kualitas laba, telah diteliti oleh beberapa peneliti sebelumnya dan memiliki hasil yang berbeda, seperti penelitian Barth et al (2008) melakukan pengujian untuk menguji apakah penggunaan IFRS berdampak terhadap kualitas informasi dan relevansi nilai laporan keuangan pada perusahaan yang berasal dari berbagai negara. Hasil penelitian menunjukkan bahwa setelah adopsi IFRS, kualitas informasi akuntansi mengalami peningkatan ditandai dengan penurunan praktik manajemen laba dan relevansi nilai data akuntansi yang mengalami peningkatan. Untuk di Indonesia, penelitian yang dilakukan oleh Syagata dan Daljono (2014), yang menguji apakah terdapat peningkatan relevansi nilai informasi akuntansi yang diproksikan dengan pengaruh relevansi nilai laba, nilai buku ekuitas, dan arus kas operasi terhadap harga saham sebelum dan sesudah penerapan konvergensi IFRS secara penuh pada perusahaan manufaktur yang terdaftar di Bursa Efek Indonesia pada tahun 2011-2012. Hasil uji koefisien determinasi $\mathrm{R}^{2}$ menunjukkan adanya peningkatan sehingga hipotesis alternatif penelitian diterima, Yaitu terdapat peningkatan relevansi nilai informasi akuntansi pada perusahan manufaktur yang listing di Bursa Efek Indonesia sesudah konvergensi IFRS. Analisis tambahan menggunakan chow test juga menunjukkan bahwa ada perbedaaan struktural antara relevansi nilai informasi akuntansi sebelum dan sesudah dilakukan konvergensi IFRS secara penuh di Indonesia

Hasil yang berbeda ditunjukan oleh peneletian Hung dan Subramayam (2007) dengan obyek penelitian perusahaan di Jerman dengan tahun penelitian antara tahun 1998 dan 2002. Hasil penelitian menunjukan bahwa tidak terdapat perbedaan yang signifikan antara nilaikualitas informasi yang ditunjukan dengan relevansi sebelum dan sesudah adopsi IAS. Hasil yang sama ditunjukan oleh penelitian Cahyonowati dan Ratmono (2012), yang menemukan bahwa aplikasi standar berbasis IFRS di Indonesia belum dapat meningkatkan kualitas informasi akuntansi. Relevansi laba akuntansi dengan keputusan investasi sebagaimana tercermin pada harga saham tidak meningkat secara signifikan pada periode setelah adopsi IFRS. Hal serupa ditunjukan oleh penelitian Hariyani dan Martini (2015) yang melakukan penelelitian pada perusahaan yang telah menerapkan IFRS yang terdaftar diBursa Efek Indonesia tahun 2010-2013, hasil penelitian menunjukan bahwa tidak terdapat terdapat perbedaan kualitas informasi akuntansi pada periode sebelum dan sesudah penerapan IFRS di Indonesia. 
Berdasarkan hasil dari peneliti-peneliti sebelumnya, dampak mengenai penerapan IFRS terhadap kualitas informasi akuntansi masih memiliki perbedaan. Seperti hasil penelitian Barth, et al (2008) dan Syagata dan Daljono (2014) yang menyatakan bahwa penerapan IFRS memberikan dampak peningkatan kualitas informasi akuntansi. Namun, Hung dan Subramayam (2007), Cahyonowati dan Ratmono (2012), dan Hariyani dan Martini (2015) menunjukan hasil yang berbeda. Yaitu tidak terdapat perbedaan ataupun peningkatan nilai kualitas informasi akuntansi sebelum ataupun sesudah penerapan IFRS.

Dengan demikian, masih terdapat ketidak konsistenan hasil penelitian dari peneliti-peneliti sebelumnya. Maka penulis berniat untuk menguji kembali dampak penerapan IFRS terhadap kualitas informasi akuntansi dan kualitas laba. Selain itu,dikutip melalui situs resmi IAI (iaiglobal.or.id) IAI sebagai standart setter di Indonesia, melalui Dewan Standar Akuntansi Keuangan (DSAK-IAI) telah berkomitmen untuk menjaga gap antara IFRS dan PSAK hanya untuk satu tahun. Implikasinya banyak standar baru yang dikeluarkan oleh IASB yang akan efektif pada tahun 2018, harus diadopsi di Indonesia pada 2019. Dengan demikian Indonesia semakin gencar melakukan program adopsi IFRS sehingga dirasa perlu untuk melakukan penelitian mengenai dampak adopsi IFRS terhadap pengguna laporan keuanga. Perbedaan antara penelitian ini dengan penelitian sebelumnya, adalah peneliti menambah tangun penelitian yaitu 4 tahun sebelumdan 4 tahun sesudah. Hal tersebut dilakukan guna mendapatkan hasil yang lebih optimal dan mendalam mengenai dampak adopsi IFRS terhadap kualitas informasi akuntansi. Berdasarkan latar belakang yang telah dipaparkan tersebut diatas, maka penulis tertarik melakukan penelitian dengan judul "Analisis Kualitas Informasi Akuntansi sebelum dan sesudah Fpenerapan International Financial Reporting Standards (IFRS) Pada Perusahaan Manufaktur Yang Terdaftar Di Bursa Efek Indonesia (BEI)"

\section{Landasan teori dan Pengembangan Hipotesis}

\subsection{Teori agency}

Teori agensi merupakan konsep yang menjelaskan hubungan kontraktual antara prinsipal dan agent. Tujuan dari teori agensi adalah pertama, untuk meningkatkan kemampuan individu (baik prinsipal maupun agen) dalam mengevaluasi lingkungan dimana keputusan harus. Kedua, untuk mengevaluasi hasil dari keputusan yang telah diambil guna mempermudah pengalokasian hasil antara prinsipal dan agen sesuai dengan kontrak kerja. Teori agensi tidak dapat dilepaskan dari kedua belah pihak diatas, baik prinsipal maupun agen merupakan pelaku utama dan keduanya mempunyai bargaining position masing-masing dalam menempatkan posisi, peran dan kedudukannya. Prinsipal sebagai pemilik modal memiliki akses pada informasi internal perusahaan sedangkan agen sebagai pelaku dalam praktek operasional perusahaan mempunyai informasi tentang operasi dan kinerja perusahaan secara riil dan menyeluruh.

Teori agensi menyatakan bahwa apabila terdapat pemisahan antara pemilik sebagai prinsipal dan manajer sebagai agen yang menjalankan perusahaan maka akan muncul permasalahan agensi karena masing-masing pihak tersebut akan selalu berusaha untuk memaksimalisasikan fungsi utilitasnya (Jensen dan Meckling, 1976). Penerapan IFRS memiliki pengaruh besar pada pelaporan keuangan perusahan dan kinerja perusahaan. Penerapan standar 
akuntansi internasional ke dalam standar akuntansi domestik bertujuan meningkatkan kredibilitas laporan keuangan, meningkatkan persyaratan itemitem pengungkapan sehingga akan terjadi peningkatan nilai perusahaan, meningkatkan akuntanbilitas manajemen dalam menjalankan perusahaan, menghasilkan informasi laporan keuangan yang lebih relevan, akurat, dan dapat diperbandingkan serta menghasilkan informasi yang valid untuk aktiva, hutang, ekuitas, pendapatan dan beban perusahaan (Petreski, 2007).

Menurut Widyaningdyah (2001) agency theory memiliki asumsi bahwa masing-masing individu semata-mata termotivasi oleh kepentingan dirinya sendiri sehingga menimbulkan konflik kepentingan antara principal dan agent. Pihak principal termotivasi mengadakan kontrak untuk mensejahterakan dirinya dengan profitabilitas yang selalu meningkat. Agen termotivasi untuk memaksimalkan pemenuhan kebutuhan ekonomi dan psikologisnya, antara lain dalam memperoleh investasi, pinjaman, maupun kontrak kompensasi. Konflik kepentingan semakin meningkat terutama karena principal tidak dapat memonitor aktivitas agen (CEO) sehari-hari untuk memastikan bahwa agen bekerja sesuai dengan keinginan pemegang saham.

\subsection{Pengaruh Penerapan IFRS terhadap Kualitas Informasi Akuntansi}

Penerapan IFRS memiliki pengaruh besar pada perusahaan yakni khususnya pada pelaporan keuangan perusahaan. Penerapan standar akuntansi internasional kedalam standar akuntansi domestik bertujuan menghasilkan laporan keuangan yang memiliki tingkat akuntabilitas tinggi dan laporan keuangan perusahaan menghasilkan informasi yang lebih relevan dan akurat, sehingga laporan keuangan akan lebih dapat diperbandingkan dan menghasilkan informasi yang valid dalam penilaian aktiva, hutang, ekuitas, pendapatan dan beban perusahaan.

Sebelum penerapan IFRS, manajemen mempunyai fleksibilitas ketika memilih metode akuntansi sehingga memotivasi manajer untuk memilih metode akuntansi atau untuk mengubah yang digunakan dalam rangka meningkatkan, menurunkan, atau meratakan laba. Barth et al. (2008) berargumen bahwa IFRS sebagai principles-based standards lebih dapat meningkatkan relevansi nilai informasi akuntansi. Hal ini karena pengukuran dengan fair value lebih dapat menggambarkan posisi dan kinerja ekonomi perusahaan. Hal ini lebih dapat membantu investor dalam mengambil keputusan investasi.

Penelitian Hung dan Subramayam (2007) dengan obyek penelitian perusahaan di Jerman dengan tahun penelitian antara tahun 1998 dan 2002. Hasil penelitian menunjukan bahwa tidak terdapat perbedaan yang signifikan antara nilai kualitas informasi yang ditunjukan dengan relevansi sebelum dan sesudah adopsi IAS. Uraian di atas tersebut menunjukkan bahwa masih belum jelas apakah IFRS dapat meningkatkan relevansi nilai informasi akuntansi. Selain itu, seperti diuraikan sebelumnya, hasil penelitian masih menunjukkan bukti yang bertentangan, tetapi apabila melihat prinsip IFRS yang menggunakan principle based dianggap dapat memberi dampak positif terhadap relevansi nilai informasi akuntansi dengan pengukuran fair value dalam penyajian laporan keuangan.

Hal tersebut dikarenakan IFRS mensyaratkan pengungkapan kondisi keuangan yang lebih rinci daripada standar akuntansi lokal. Sesuai dengan tujuan IFRS sendiri yaitu memastikan bahwa laporan keuangan intern perusahaan untuk 
periode-periode yang dimaksudkan dalam laporan keuangan tahunan mengandung informasi berkualitas tinggi dan transparan sehingga pemegang saham tidak salah dalam pengambilan keputusan, hipotesis yang dapat diajukan adalah:

$\mathrm{Ha}_{1}$ : Terdapat peningkatan Kualitas Informasi Akuntansi setelah penerapan standar akuntansi berbasis IFRS pada perusahaan manufaktur

\subsection{Model Penelitian}

\section{Gambar 1}

\section{Analisis Kualitas Informasi Akuntansi Sebelum dan Sesudah Penerapan International Financial Reporting Standards (IFRS) Pada Perusahaan Manufaktur Yang Terdaftar Di Bursa Efek Indonesia (BEI)}

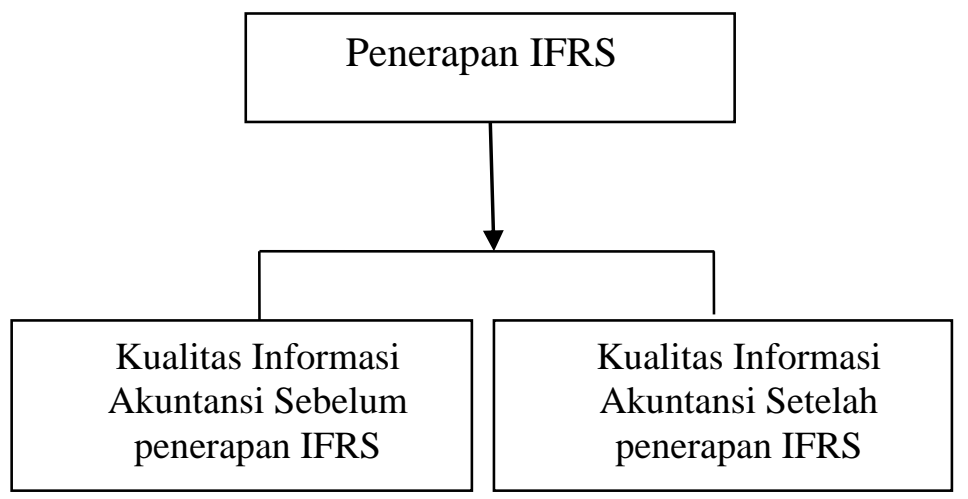

\section{Meteodelogi Penelitian}

\section{1 sampel}

Dalam penelitian ini yang menjadi objek penelitian adalah perusahaan manufaktur yang terdapat di Bursa Efek Indonesia dengan periode pengamatan 2008-2016. Selain dari Bursa Efek Indonesia, sumber data yang digunakan dalam penelitian ini diperoleh www.finance.yahoo.com. Pemilihan sampel dilakukan dengan metode purposive sampling. Berdasarkan data yang diperoleh terdapat 144 perusahaan manufaktur yang terdaftar di Bursa Efek Indonesia pada periode 2016.

\subsection{Definisi operasional variabel}

\subsubsection{Kualitas Informasi Akuntansi}

Kualitas informasi akuntansi dalam penelitian ini ditunjukan dengan nilai relevansi informasi akuntansi. Pengujian relevansi informasi akuntansi menggunakan model harga (price model) yang dikembangkan oleh Ohlson (1995). Indra dan Syam (2004) menjelaskan bahwa pada saat model harga digunakan sebagai model penilaian, relevansi nilai dari data akuntansi mengalami peningkatan sejalan dengan waktu (over time). Sedangkan pada saat model return digunakan sebagai model penilaian, relevansi nilai dari data akuntansi menunjukkan penurunan sejalan dengan waktu. Price model yang dikembangkan oleh Ohlson (1995) sebagai berikut ini:

$$
P i t+1=a 0+a 1 \text { EPSit }+a 2 \mathrm{BVit}+e \text { it }
$$


Pada penelitian ini pengukuran variabel nilai relevansi informasi akuntansi konsisten dengan penelitian-penelitian sebelumnya Cahyonowati dan Ratmono (2012) :

$P i t+1=a 0+a 1$ EPSit $+a 2 \mathrm{BVit}+a 3 \mathrm{CFOit}+e$ it

Keterangan :

Pit $+1=$ Harga saham tanggal 31 Maret dalam $\mathrm{t}+1$

EPS = Laba bersih ekuitas per lembar saham (earnings per share)

BVit = Nilai buku ekuitas per lembar saham (book value per share)

CFOit = Arus kas operasi per lembar saham

Pada penelitian ini, pengujian kualitas informasi dilakukan secara terpisah, antara sebelum dan sesudah pengadopsian IFRS. Pengujian relevansi memfokuskan pada perubahan nilai Adjusted $\mathrm{R}^{2}$ setelah adopsi IFRS. Jika nilai Adjusted $\mathrm{R}^{2}$ meningkat secara signifikan maka dapat disimpulkan bahwa informasi akuntansi meningkatkan relevansi nilainya karena adopsi IFRS (Karampinis dan Hevas, 2011).

\subsection{Metode Analisis Data}

Dalam metode estimasi model regresi dengan menggunakan data panel dapat dilakukan melalui tiga pendekatan, yaitu Common Effect Model atau Pooled Least Square (PLS), Fixed Effect Model (FE) dan Random Effect Model (RE). Dan untuk memilih model yang paling tepat terdapat beberapa pengujian yang dapat dilakukan yaitu dengan uji Chow, uji Hausman dan uji uji Lagrange Multiplier (Gujarati \& Porter, 2015).

Pengujian relevansi memfokuskan pada perubahan nilai Adjusted $\mathrm{R}^{2}$ setelah adopsi IFRS. Jika nilai Adjusted $\mathrm{R}^{2}$ meningkat secara signifikan maka dapat disimpulkan bahwa informasi akuntansi meningkatkan relevansi nilainya karena adopsi IFRS (Karampinis dan Hevas, 2011).

\section{Hasil dan Diskusi}

Pengujian kualitas informasi akuntansi yang diukur dengan relevansi memfokuskan pada perubahan nilai Adjusted $\mathrm{R}^{2}$ setelah adopsi IFRS. Jika nilai Adjusted $\mathrm{R}^{2}$ meningkat secara signifikan maka dapat disimpulkan bahwa informasi akuntansi meningkatkan relevansi nilainya karena adopsi IFRS (Karampinis dan Hevas, 2011). Dalam pengujian hipotesis untuk kualitas informasi akuntansi sebelum ataupun sesudah penerapan IFRS model yang digunakan adalah Random Effect. Berikut adalah hasil uji Random Effect.

Untuk menjawab hipotesis yang telah diajukan sebelumnya, yaitu penerapan standar akuntansi berbasis IFRS meningkatkan kualitas informasi akuntansi pada perusahaan manufaktur yang terdaftar di Bursa Efek Indonesia. Dapat diamati dalam tabel 4.5 berikut ini. 
Tabel 4.5

Perubahan Kualitas Informasi Akuntansi Sebelum dan setelah Penerapan IFRS

\begin{tabular}{|l|l|l|c|}
\hline \multirow{2}{*}{ Nilai } & Sebelum & Sesudah & \multirow{2}{*}{$\begin{array}{c}\text { Perubahan } \\
\text { Setelah IFRS }\end{array}$} \\
\cline { 2 - 3 } & Coefficient & Coefficient & -13.346409 \\
\hline EPS & $13.348766^{*}$ & 0.002357 & 3.240716 \\
\hline BV & -0.724624 & $2.516092^{*}$ & 3.180851 \\
\hline Adjusted $R$-squared & 0.663165 & 0.844018 & 0.18 \\
\hline
\end{tabular}

*Berpengaruh signifikan a 5\%

Pada tabel 4.5, menunjukan nilai Adjusted $R$-squared untuk relevansi informasi akuntansi sebelum IFRS yaitu sebesar 0,663165 atau 66,3165\%. Kemudian nilai Adjusted $R$-squared relevansi informasi akuntansi setelah IFRS mengalami peningkatan menjadi 0,844018 atau $84,4018 \%$. Itu berarti terdapat peningkatan Adjusted $R$-squared sebesar 0,180851 atau sebesar 18,0851\%. Dengan demikian, maka Hipotesis 1 terdukung. Yaitu penerapan standar akuntansi berbasis IFRS meningkatkan kualitas informasi akuntansi.

Analisis lebih lanjut dapat diperoleh dengan mengamati nilai coefficient pada laba bersih perlembar saham (EPS) dan nilai buku ekuitas (BV) (Cahyonowati dan Ratmono, 2012). Nilai koefisien EPS menurun dari 13.47947 menjadi 0.002357, terjadi penurunan sebesar 13.346409. Sedangkan Coefficient untuk nilai buku ekuitas (BV) memiliki coefficient yang negatif pada periode sebelum adopsi IFRS yaitu -0.724624 menjadi positif senilai 2.516092 atau terjadi peningkatan sebesar 3.240716. Hasil ini menunjukkan bahwa terjadi peningkatkan relevansi nilai Book Value. untuk dimensi laba bersih perlembar saham (EPS) meskipun nilai coefficient EPS mengalami penurunan setelah penerapan IFRS, tetapi nilai EPS masih tetap memiliki arah yang positif terhadap harga saham. Dengan demikian, nilai relevansi BV lebih tinggi dibandingkan nilai relevansi EPS setelah penerapan IFRS.

Nilai buku ekuitas merupakan suatu informasi yang menyajikan nilai bersih sumber daya perusahaan dalam jangka panjang (Wibowo, 2010). Menurut Dewi dan Kristanto (2018), Nilai buku ekuitas yang merupakan aset bersih perusahaan dapat digunakan untuk mengetahui kondisi perusahaan yang sebenarnya sehingga investor dan pengguna laporan keuangan lainnya dapat menggunakan informasi tersebut sebagai dasar keputusan investasinya, sedangkan nilai laba dapat digunakan untuk menilai kinerja perusahaan selama satu periode tertentu sehingga para investor dan pengguna laporan keuangannya lainnya seperti pemerintah dapat menggunakan informasi tersebut sebagai dasar pengambilan keputusan investasi maupun dasar penghitungan perpajakan. Sehingga hasil penelitian yang menunjukan bahwa nilai relevansi BV lebih tinggi dibandingkan nilai relevansi EPS setelah penerapan IFRS artinya setelah adopsi IFRS investor lebih memperhatikan relevansi nilai buku ekuitas yang memberikan informasi mengenai sumber daya perusahaan dalam jangka panjang dibanding nilai laba dapat digunakan untuk menilai kinerja perusahaan selama satu periode tertentu.

Hasil penelitian ini mendukung penelitian Barth et al (2008), Bartov et al (2002) dan Syagata dan Daljono (2014) yaitu setelah adopsi IFRS, kualitas informasi akuntansi mengalami peningkatan yang ditandai dengan peningkatan 
relevansi nilai informasi akuntansi. Kemudian penelitian ini tidak mendukung hasil penelitian dari Hung dan Subramayam (2007), Cahyonowati dan Ratmono (2012) dan Hariyani dan Martini (2015) yang menyatakan bahwa tidak terdapat terdapat perbedaan kualitas informasi akuntansi pada periode sebelum dan sesudah penerapan IFRS di Indonesia.

Pengadopsian IFRS memiliki pengaruh besar pada perusahaan yakni khususnya pada pelaporan keuangan perusahaan. Pengadopsian standar akuntansi internasional kedalam standar akuntansi domestik bertujuan menghasilkan laporan keuangan yang memiliki tingkat akuntabilitas tinggi dan laporan keuangan perusahaan menghasilkan informasi yang lebih relevan dan akurat, sehingga laporan keuangan akan lebih dapat diperbandingkan dan menghasilkan informasi yang valid dalam penilaian aktiva, hutang, ekuitas, pendapatan dan beban perusahaan. Barth et al (2008) menyatakan bahwa IFRS sebagai principles-based standards lebih dapat meningkatkan relevansi nilai informasi akuntansi. Hal ini karena pengukuran dengan fair value lebih dapat menggambarkan posisi dan kinerja ekonomi perusahaan. Hal ini lebih dapat membantu investor dalam mengambil keputusan investasi.

IFRS mensyaratkan pengungkapan kondisi keuangan yang lebih rinci daripada standar akuntansi lokal. Sesuai dengan tujuan IFRS sendiri yaitu memastikan bahwa laporan keuangan intern perusahaan untuk periode-periode yang dimaksudkan dalam laporan keuangan tahunan mengandung informasi berkualitas tinggi dan transparan sehingga pemegang saham tidak salah dalam pengambilan keputusan.

\section{Kesimpulan, Keterbatasan dan Saran Penelitian}

Penelitian ini bertujuan untuk menganalisis pengaruh penerapan International Financial Reporting Standards (IFRS) terhadap kualitas informasi akuntansi pada perusahaan yang terdaftar di Bursa Efek Indonesia (BEI). Hipotesis yang diajukan terdukung. Yaitu penerapan standar akuntansi berbasis IFRS meningkatkan kualitas informasi akuntansi pada perusahaan manufaktur yang terdaftar di Bursa Efek Indonesia. Nilai relevansi BV lebih tinggi dibandingkan nilai relevansi EPS setelah penerapan IFRS. Hal tersebut ditunjukan dengan meningkatnya nilai coefficient $\mathrm{BV}$ dan menurunnya nilai coefficient EPS setelah penerapan IFRS.

Penelitian ini masih memiliki keterbatasan seperti, dalam penelitian ini hanya menggunakan sampel berupa perusahaan manufaktur saja. Hal tersebut dilakukan untuk dapat lebih mengontrol variabel penganggu. Akan tetapi dikarenakan hal tersebut pulalah maka penelitian ini hanya mampu memberi gambaran mengenai kualitas informasi akuntansi penerapan standar akuntansi sebelum dan sesudah penerapan laporan keuangan berberbasis IFRS terhadap perusahaan manufaktur saja. Sedangkan pengadopsian IFRS adalah untuk seluruh sektor industri dan akan memberikan dampak yang berbeda kepada-masingmasing sektor industri yang ada.

Berdasarkan hasil kesimpulan, penulis memberikan saran kepada peneliti selanjutnya agar memperluas sampel dengan cara membagi sampel dalam beberapa sektor industri. Seperti sektor keuangan, pertambangan dan properti. 
Kemudian membandingkan hasil pengaruh penerapan IFRS terhadap kualitas informasi akuntansi pada beberapa sector tersebut.

\section{DAFTAR PUSTAKA}

Barth, M. E., Landsman, W. R. \& Lang, M. 2008. International Accounting Standards and Accounting Quality. Journal of Accounting Research, 467498.

Bartov, E., Goldberg, S. \& Kim, M. 2002. "Comparative Value Relevance Among German, U.S. and International Accounting Standards: A German Stock Market Perspective". Journal of Accounting, Auditing and Finance, 20, 95-119.

Beaver, William H. 1968.The Information Content of Earnings.

Cahyonowati, Nur dan Dwi Ratmono. 2012. Adopsi IFRS dan Relevansi Nilai Informasi Akuntansi. Journal Akuntansi dan Keuangan. Vol 14 No 2: 105115.

Capkun, V., Cazavan, J.A., Jeanjean, T., and Lawrence, A. 2008. Earnings management and value relevance during the mandatory transition from Local GAAPs to IFRS in Europe. Working paper.

Choi, Frederick D.S., Carol Ann Frost, Garry K Meek. 1999. International Accounting. 3th edition. United Stated: Prentice Hall International.

Dewi, Anisah Kusuma dan Kristanto, Ari Budi. 2018. Konvergensi IFRS di Indonesia: Apakah Relevansi Nilai Relatif dan Inkremental Informasi Akuntansi Terdampak?. Jurnal Dinamika Akuntansi dan Bisnis Vol. 5(2), 2018, pp 221-234

Easton, Peter D., and Trevor Harris. 1991. Earnings as an Explanatory Variable for Returns. Journal of Accounting Research 29, no. 1: 19-36.

Francis, J. \& K. Schipper. 1999. Have Financial Statement Lost Their Relevance?. Journal of Accounting Research (Antumn): 319-352.

Gjerde, Oystein; Kjell Hendry Knivsfla \& Frode Saettem. 2008. The ValueRelevance of Adopting IFRS: Evidence from 145 NGAAP Restatements. Departement of Finance and management Science

Ghozali Imam dan A. Chariri. 2007. Teori Akuntansi. Semarang: Badan Penerbit Universitas Diponegoro.

Gujarati dan Porter. 2015. Dasar-Dasar Ekonometrika. Jakarta : Salemba Empat Harahap,S.S, 2013. Teori Akuntansi Edisi Revisi. Jakarta: Raja Grafindo Persada

Hariyani, Reni., dan Martini. 2015. Analisis Komparatif Kualitas Informasi Akuntansi Dan Kinerja Keuangan Sebelum Dan Sesudah Penerapan International Financial Reporting Standard, Jurnal Akuntansi dan Keuangan. Vol. 4.

Hung, Mingyi., and Subramanyam, K.R. 2007. Financial Statement Effect of Adopting International Accounting Standards: the case of Germany. Review of Accounting Studies, Vol.12, Issue 4.

Iatridis, George. 2010, International Financial Reporting Standards and the quality financial statements information. International Review of Financial Analysis 19 (2010) 193-204.

Ikatan Akuntan Indonesia 2009. Standar Akuntansi Keuangan. Jakarta : Salemba Empat. 
Ikatan Akuntan Indonesia 2015. Standar Akuntansi Keuangan. Jakarta : Salemba Empat.

Immanuella, Intan.2009. Adopsi Penuh dan Harmonisasi Standar Akuntansi Internasional. Jurnal Fakultas Ekonomi :Universitas Widya Mandala Madiun.

Jensen, Michael C. dan W.H. Meckling. 1976. Theory of The Firm: Managerial Behavior, Agency Cost and Ownership Structure. www.ssrn.com.

Karampinis, N. dan Hevas, D. 2011. "Mandating IFRS in an Unfavorable Environment: The Greek Experience". The International Journal of Accounting.

Ohlson, J. 1995. Earning, Book Values, and Dividends In Security Valuation. Comteporary Accounting Research (Spring): 661-688.

Petreski, Marjan, 2006. The Impact of International Accounting Standard on Firms. http://papers.ssm.com

Santy, Prima. 2013. Pengaruh Adopsi IFRS terhadap Manajemen Laba Pada Perusahaan Perbankan di Bursa Efek Indonesia. Jurnal akuntansi.

Schipper, K., dan L. Vincent. 2003. Earnings quality. Accounting Horizons 17:97-110.

Simbolon, Harry Andrian. 2010. Value Relevance. (www.akuntansibisnis.wordpress.com) (28/11/2013)

Sugiyono. 2013. Metode Penelitian Bisnis. Bandung: CV. Alfabeta.

Syagata, Gupitasari syahbi., dan Daljono. 2014. Analisis Komparasi Relevansi Nilai Informasi Akuntansi Sebelum dan Sesudah Konvergensi IFRS di Indonesia (Studi Empiris pada Perusahaan Manufaktur yang terdaftar di BRI Periode 2011-2012). Diponogoro Journal of Accounting, Vol 3, No.3,1-11.

Waryanti, 2009. Pengaruh Karakteristik Perusahaan terhadap Pengungkapan Sosial pada Perusahaan Manufaktur di Bursa Efek Indonesia. Jurnal Ekonomi. Akuntansi UNDIP.

Wibowo, R. H. (2010). Manajemen laba dan relevansi nilai informasi akuntansi laba dan nilai buku. Jurnal Akuntansi; 1(2).

Widyaningdyah, Agnes Utari.(2001). Analisis Faktor-Faktor Yang Berpengaruh Terhadap Earning Management Pada Perusahaan Go Public Di Indonesia. Jurnal Akuntansi \& Keuangan, Vol. 3, No. 2, h. 89-101.

www. akuntansionline, 2013. diakses 02 November 2016. Jam 18.45.

www.iaiglobal.or.id

www.idx.co.id 